\title{
FORA UM SORRISO
}

\section{Tatiana de Freitas Massuno ${ }^{1}$}

Fora um sorriso, definitivamente. Não um sorriso largo que revelasse seus dentes corretamente ajustados, embora pouco amarelados pelo constante desgaste da cafeína e do tabaco. Ajustados, no lugar a eles concedido, nem mais para frente, nem mais para trás, muito menos repuxados para os lados. Simplesmente pequenas colunas levemente amareladas que se erguiam, firmes, colunas bem fincadas.

Haveria algum sorriso seu tão largo a ponto de revelar os dentes? Sorriria além de uma pequena elevação dos lábios, quase um muxoxo? Afinal, fora mesmo um sorriso ou apenas um ato involuntário de seus lábios, um ato de reprovação? Talvez percebesse que sua voz titubeava, tentando achar um solo menos movediço em meio a seus próprios questionamentos. A voz devia se desvincular do pensamento de que brotava. Mal o pensamento surgia e tantas outras questões impediam que a voz decretasse: “É isso!".

O som de sua voz vinha sempre atrasado, sempre um passo atrás, sempre passado. E com a voz cambaleante, desviando-se de caminhos tortuosos, enfim, conseguira após tremendo esforço afirmar: "É isso!". Automaticamente procurara seus olhos, buscando alguma alteração em seu rosto que confirmasse que a ouvira decretar, que a ouvira ir além de si, superando as próprias limitações do pensamento que estrangulava a sua voz. Sua voz era nada mais que isso: um pequeno suspiro que se apagava, um pequeno momento de êxtase, lá atrás, no passado. Satisfeita consigo mesma, abaixara os olhos. Fora um sorriso. As vozes ao seu redor não mais existiam.

\footnotetext{
${ }^{1}$ Doutoranda em Literatura Comparada (UERJ).
} 
Grande gritaria, lá fora. As pessoas corriam, esbarravam-se, esbravejavam. Não há de ser nada, pensou consigo. Continuava, calmamente, a observar a xícara de café que trazia entre os dedos. Sentia o calor do recipiente esquentar as mãos. Sentiu um leve prazer em ter a xícara confortando-as. Não mais vazias. Seu olhar já quase se perdia na imensidão daquele líquido uniforme quando sentira suas mãos arder. O líquido em suas mãos, seus braços, suas roupas. A xícara recém-transformada em cacos parecia ocupar todo o espaço de seu quarto. $\mathrm{O}$ mesmo barulho que a havia sobressaltado continuava agora. Intermitentemente. Não sabia mais para onde fugir sem que tivesse as solas dos pés cortadas pelos pedaços de xícara quebrada.

Deixou-se quieta por um instante. Não se movia. Até que o próximo estrondo a fez correr, apesar dos cacos, através deles, até que se percebesse tremendo embaixo da cama. Quando seu corpo finalmente se acalmara, viu a porta de seu quarto abrir. Dela saiu um homem de meia-idade, parcialmente calvo, os óculos aumentando a amplidão de seu olhar. Ao ver seu rosto se acalmou. Foi em sua direção, quando, enfim, o homem proferiu suas primeiras palavras: "É, você poderia ter sido muito boa...". Sem saber ao certo o que falar, apenas retrucou: “Poderia? Não posso mais?”. "Não, você mudou!", o som grave da voz entupira seus ouvidos que não percebiam mais nada, não captavam qualquer outro som a não ser a repetição calma das mesmas palavras, os mesmos sons, perfeitamente soletrados, você mudou, você mudou, não, você mudou, você mudou, não...

Abrira os olhos. No teto, apenas o ventilador em seu movimento ininterrupto. Sentia o vento a cobrir-lhe toda a extensão do corpo, como que apaziguando-a. Fora uma reprovação, definitivamente. Mais uma vez na tentativa de escapar ao isolamento de ser isso: um corpo, um espaço fechado em si mesmo, um organismo autônomo que funcionava apesar de si, apesar daquilo que se processava, onde? Em um outro âmbito, sim. Algo se processava além disso que se acostumou a habitar. Sim, habitava o seu corpo. Habitava por pura acomodação. Não que se sentisse acomodada nele, muito pelo contrário, 
seu corpo cada vez mais limitava aquilo que poderia ser, ou era, ou poderia ter sido. Seu corpo era apenas limite...intransponível.

$\mathrm{Na}$ tentativa de superar esse limite, de atravessar a extensão incomensurável que separava todos os seres, pôs-se a falar. Pôs-se a decretar teorias, implodindo os limites possíveis, instaurados, necessários. As palavras saíam de si: “É isso!", e por onde passavam, deixavam aquela sensação de ardência. As palavras, que não queriam sair, mas que mesmo assim eram carreadas por algo maior que elas, o faziam, não, no entanto, sem demonstrar a própria insatisfação. As palavras resistentes à fala atritavam-se na garganta, como que tentando ganhar mais tempo. Não estavam ainda prontas para aquilo a que eram designadas. Mas saíram: “É isso!", diziam. Ao sentir a garganta pedir por clemência pelo esforço desnecessário ao que fora submetida, procurara seus olhos, automaticamente. Envergonhada de si mesma, abaixara os olhos. Fora uma reprovação. As vozes ao seu redor não mais existiam

Vira, como certeza, algo a se mover. Não sabia ainda se era grande ou pequeno, mas vira algum tipo de vulto indo na direção da cama. Embaixo da cama, na verdade. Por alguns segundos se perguntou se deveria checar o que era. E se fosse algo maior do que esperava? Ela, assim, sozinha...o que poderia fazer além de gritar, se esconder? Parada, imaginava que se talvez não fosse ver o que era aquilo embaixo de sua cama, aquilo seja lá o que fosse, poderia aumentar, se multiplicar, até que estivesse, ela, soterrada até o pescoço de vultos negros que se moviam. Ela rodeada de pequenas e grandes criaturinhas que caminhavam, corriam, pela extensão de seu quarto, pela extensão de seu corpo, até que encontrassem o caminho de sua boca e a soterrassem também por dentro. Indo ao encontro de suas entranhas. Não deixaria. Foi em direção à cama. Lentamente, abaixou-se. A criatura fugiu. Atrás do armário. Era maior do que imaginava. De repente os olhos avermelhados da criatura encontraram os seus. Não havia medo em seu olhar. Rapidamente a criatura se movia. Em sua direção agora. Um grito saiu de si.

Não, não acordara. O corpo a seu lado continuava inerte. De si saiam apenas pequenos sons, nada ameaçadores. Apenas sons. Sem sentido. Talvez 
sonhasse. "É isso!", disse. Automaticamente procurou seu olhar. Não, não estava lá. “É isso!”, continuou. 